\title{
Amphimedonoic acid and psammaplysene E, novel brominated alkaloids from Amphimedon sp.
}

\author{
Pierre-Eric Campos ${ }^{\mathrm{a}}$, Jean-Luc Wolfender ${ }^{\mathrm{b}}$, Emerson F. Queiroz ${ }^{\mathrm{b}}$, Laurence Marcourt $^{\mathrm{b}}$, \\ Ali Al-Mourabit ${ }^{\mathrm{c}}$, Nicole De Voogd ${ }^{\mathrm{d}}$, Bertrand Illien ${ }^{\mathrm{a}}$, Anne Gauvin-Bialecki ${ }^{\mathrm{a}, *}$ \\ ${ }^{a}$ Laboratoire de Chimie des Substances Naturelles et des Sciences des Aliments, Faculté des Sciences et Technologies, Université de La Réunion, 15 Avenue René Cassin, CS 92003, \\ 97744 Saint-Denis Cedex 9, La Réunion, France \\ ${ }^{\mathrm{b}}$ School of Pharmaceutical Sciences, EPGL, University of Geneva, University of Lausanne, Quai Ernest-Ansermet 30, CH-1211 Geneva 4, Switzerland \\ ${ }^{c}$ Institut de Chimie des Substances Naturelles, CNRS UPR 2301, Univ. Paris-Sud, Université Paris-Saclay, 1, av. de la Terrasse, 91198 Gif-sur-Yvette, France \\ ${ }^{\mathrm{d}}$ Naturalis Biodiversity Center, Darwinweg 2, 2333 CR Leiden, Netherlands
}

\begin{abstract}
A B S T R A C T
Examination of the $\mathrm{CH}_{2} \mathrm{Cl}_{2}-\mathrm{MeOH}$ (1:1) extract from the Madagascan sponge Amphimedon sp. highlighted two new brominated alkaloids, amphimedonoic acid (1) and psammaplysene E (2), along with the known 3,5-dibromo-4methoxybenzoic acid (3). Their structures were elucidated by 1D and 2D NMR spec-troscopy and HRESIMS data.
\end{abstract}

\begin{abstract}
Marine sponges have been reported as a major source of bioactive secondary metabolites with a wide variety of unusual structures. ${ }^{1}$ The genus Amphimedon has been known to produce various potent bioactive compounds, especially alkaloids with unique structures. ${ }^{2-4}$ As part of our continued search for structurally unique metabolites from marine invertebrates, ${ }^{5-7}$ the sponge Amphimedon sp., collected from the Mitsio Islands, Madagascar, was investigated. These investigations afforded two new brominated alkaloids, amphimedonoic acid (1) and psammaplysene E (2), along with the known 3,5-dibromo-4-methoxybenzoic acid (3) ${ }^{8,9}$ Herein, the isolation and structure elucidation of 1-3 are described.

The sponge Amphimedon sp. (36.2 g, wet weight) collected off the Mitsio Islands, Madagascar, was extracted with $\mathrm{CH}_{2} \mathrm{Cl}_{2} / \mathrm{MeOH}$ (1:1). The crude extract ( $1.5 \mathrm{~g}$ ) was subjected to MPLC over silica gel and separated into ten fractions (F1-F10) using a combination of isohexane, EtOAc and MeOH of increasing polarity. F9 (15 mg) was subjected to a subsequent reversed phase semi-preparative HPLC separation to yield pure compound $2(0.7 \mathrm{mg})$. F10 (32 mg) was subjected to a reversed phase semi-preparative HPLC separation and led to the isolation of pure compounds 1 ( $2.8 \mathrm{mg}), 2$ (1.3 $\mathrm{mg}$ ) and 3 (1.0 $\mathrm{mg}$ ) (Fig. 1).
\end{abstract}

\footnotetext{
* Corresponding author.

E-mail address: anne,bialecki@univ-reunion,fr (A. Gauvin-Bialecki).
}

Amphimedonoic acid (1) was obtained as a colorless oil. The high resolution electrospray mass spectrum exhibited a molecular ion $[\mathrm{M}+\mathrm{H}]^{+}$as a cluster of peaks $m / z \quad 302.0388 / 304.0388$ in a $1: 1$ ratio, an isotope pattern characteristic of a brominated compound. Accordingly, based on HRESIMS, the molecular formula $\mathrm{C}_{12} \mathrm{H}_{16} \mathrm{BrNO}_{3}$ (calcd for $\mathrm{C}_{12} \mathrm{H}_{17}{ }^{79} \mathrm{BrNO}_{3}^{+}, 302.0386$ ), with five degrees of unsaturation, was determined. The ${ }^{1} \mathrm{H}$ and ${ }^{13} \mathrm{C}$ NMR data displayed resonances and correlations for one carboxylic acid group, one 1,2,4-trisubstituted aromatic ring, three methylenes, one of which was oxygenated and two $N$-methyl groups (Table 1 ). The benzoic acid moiety was suggested by HMBC correlations from $\mathrm{H}-3\left(\delta_{\mathrm{H}} 8.10\right)$ to C-1 $\left(\delta_{\mathrm{C}} 172.6\right), \mathrm{C}-4\left(\delta_{\mathrm{C}} 111.7\right), \mathrm{C}-5\left(\delta_{\mathrm{C}} 157.6\right), \mathrm{C}-7$ $\left(\delta_{\mathrm{C}} 131.1\right)$, from $\mathrm{H}-6\left(\delta_{\mathrm{H}} 6.97\right)$ to $\mathrm{C}-2\left(\delta_{\mathrm{C}} 132.2\right), \mathrm{C}-4, \mathrm{C}-5$ and from $\mathrm{H}-7\left(\delta_{\mathrm{H}} 7.83\right)$ to $\mathrm{C}-3\left(\delta_{\mathrm{C}} 135.3\right)$ and C-5 (Fig. 2). The chemical shift $\left(\delta_{\mathrm{C}} 111.7\right)$ of the quaternary carbon $\mathrm{C}-4$ placed the bromine substituent at $\mathrm{C}-4$. The substitution of $\mathrm{C}-5$ was suggested by its chemical shift $\left(\delta_{\mathrm{C}} 157.6\right)$ and also by the HMBC correlation from $\mathrm{H}-8\left(\delta_{\mathrm{H}}\right.$ 4.21) to $\mathrm{C}-5$. Interpretation of the ${ }^{1} \mathrm{H}-{ }^{1} \mathrm{H}$ COSY correlations between $\mathrm{H}-8, \mathrm{H}-9$ and $\mathrm{H} 10$, revealed the propyl spin system C-8-C-9-C-10. The substitution of the amine moiety was determined by HMBC correlations from $\mathrm{H}-10\left(\delta_{\mathrm{H}} 3.21\right)$ to $\mathrm{C}-11, \mathrm{C}-12$ $\left(\delta_{\mathrm{C}} 43.9\right)$ and from $\mathrm{H}-11, \mathrm{H}-12\left(\delta_{\mathrm{H}} 2.81\right)$ to $\mathrm{C}-10\left(\delta_{\mathrm{C}} 56.7\right), \mathrm{C}-11$ and C-12 (Fig. 2).

Psammaplysene E (2) was obtained as a colorless oil. The high resolution electrospray mass spectrum showed four isotopic peaks 
<smiles>CN(C)CCCOc1ccc(C(=O)O)cc1Br</smiles>

amphimedonoic acid (1)<smiles>COc1c(Br)cc(C(=O)O)cc1Br</smiles>

3,5-dibromo-4-methoxybenzoic acid (3)<smiles>COc1c(Br)cc(/C=C/C(=O)NCCc2cc(Br)c(OCCCN(C)C)c(Br)c2)cc1Br</smiles>

psammaplysene $E$ (2)

Fig. 1. Structures of isolated compounds 1-3.

Table 1

${ }^{1} \mathrm{H}$ and ${ }^{13} \mathrm{C}$ NMR data for amphimedonoic acid (1), psammaplysene $\mathrm{E}(2)$ and 3,5-dibromo-4-methoxybenzoic acid (3) $\left({ }^{1} \mathrm{H} 500 \mathrm{MHz},{ }^{13} \mathrm{C} 125 \mathrm{MHz}, \mathrm{CD} \mathrm{OD}\right)$.

\begin{tabular}{|c|c|c|c|c|c|c|}
\hline \multirow[t]{2}{*}{ Position } & \multicolumn{2}{|l|}{1} & \multicolumn{2}{|l|}{2} & \multicolumn{2}{|l|}{3} \\
\hline & $\delta_{\mathrm{C}}$ & $\delta_{\mathrm{H}}(\mathrm{J}$ in $\mathrm{Hz})$ & $\delta_{\mathrm{C}}$ & $\delta_{\mathrm{H}}(\mathrm{J}$ in $\mathrm{Hz})$ & $\delta_{\mathrm{C}}$ & $\delta_{\mathrm{H}}(\mathrm{J}$ in $\mathrm{Hz})$ \\
\hline 1 & 172.6 & - & 167.6 & - & 171.0 & - \\
\hline 2 & 132.2 & - & 123.6 & $6.52(1 \mathrm{H}, \mathrm{d}, 15.7)$ & - & - \\
\hline 3 & 135.3 & $8.10(1 \mathrm{H}, \mathrm{d}, 1.9)$ & 138.1 & $7.37(1 \mathrm{H}, \mathrm{d}, 15.7)$ & 134.7 & $8.12(1 \mathrm{H}, \mathrm{s})$ \\
\hline 4 & 111.7 & - & 135.1 & - & 118.0 & - \\
\hline 5 & 157.6 & - & 132.8 & $7.79(1 \mathrm{H}, \mathrm{s})$ & 156.6 & - \\
\hline 6 & 112.9 & $6.97(1 \mathrm{H}, \mathrm{d}, 8.5)$ & 119.3 & - & 118.0 & - \\
\hline 7 & 131.1 & $7.83(1 \mathrm{H}, \mathrm{dd}, 8.6,2.0)$ & 156.1 & - & 134.7 & $8.12(1 \mathrm{H}, \mathrm{s})$ \\
\hline 8 & 67.2 & $4.21(2 \mathrm{H}, \mathrm{t}, 5.7)$ & 119.3 & - & 60.8 & $3.87(3 \mathrm{H}, \mathrm{s})$ \\
\hline 9 & 25.9 & $2.23(2 \mathrm{H}, \mathrm{m})$ & 132.8 & $7.79(1 \mathrm{H}, \mathrm{s})$ & - & - \\
\hline 10 & 56.7 & $3.21(2 \mathrm{H}, \mathrm{t}, 7.4)$ & 60.9 & $3.88(3 \mathrm{H}, \mathrm{s})$ & - & - \\
\hline 11 & 43.9 & $2.81(3 \mathrm{H}, \mathrm{s})$ & 41.5 & $3.51(2 \mathrm{H}, \mathrm{t}, 7.1)$ & - & - \\
\hline 12 & 43.9 & $2.81(3 \mathrm{H}, \mathrm{s})$ & 34.9 & $2.82(2 \mathrm{H}, \mathrm{t}, 7.0)$ & - & - \\
\hline 13 & - & - & 139.9 & - & - & - \\
\hline 14 & - & - & 134.2 & $7.50(1 \mathrm{H}, \mathrm{s})$ & - & - \\
\hline 15 & - & - & 118.7 & - & - & - \\
\hline 16 & - & - & 152.3 & - & - & - \\
\hline 17 & - & - & 118.7 & - & - & - \\
\hline 18 & - & - & 134.2 & $7.50(1 \mathrm{H}, \mathrm{s})$ & - & - \\
\hline 19 & - & - & 71.6 & $4.07(2 \mathrm{H}, \mathrm{t}, 5.8)$ & - & - \\
\hline 20 & - & - & 27.4 & $2.15(2 \mathrm{H}, \mathrm{m})$ & - & - \\
\hline 21 & - & - & 57.1 & $3.07(2 \mathrm{H}, \mathrm{t}, 7.3)$ & - & - \\
\hline 22 & - & - & 44.3 & $2.63(3 \mathrm{H}, \mathrm{s})$ & - & - \\
\hline 23 & - & - & 44.3 & $2.63(3 \mathrm{H}, \mathrm{s})$ & - & - \\
\hline
\end{tabular}

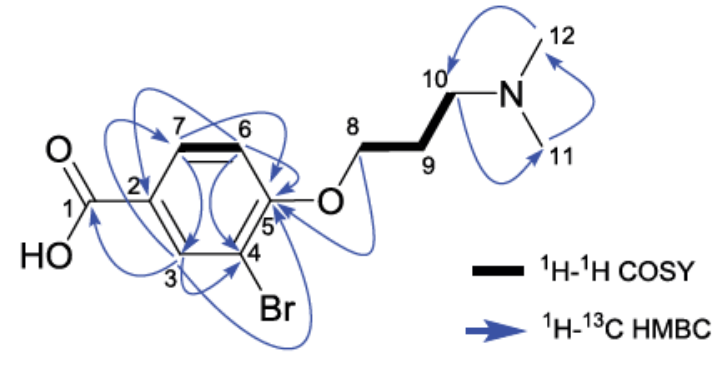

Fig. 2. Key ${ }^{1} \mathrm{H}-{ }^{1} \mathrm{H}$ COSY and ${ }^{1} \mathrm{H}-{ }^{13} \mathrm{C}$ HMBC correlations for $\mathbf{1}$.

at $m / z 694.8758,696.8740,698.8723,700.8702,702.8691[\mathrm{M}+\mathrm{H}]^{+}$ in a 1:4:6:4:1 ratio, respectively, indicating the presence of two bromine atoms in the molecule. The HRESIMS allowed assignment of the molecular formula as $\mathrm{C}_{23} \mathrm{H}_{27} \mathrm{Br}_{4} \mathrm{~N}_{2} \mathrm{O}_{3}^{+}$(calcd for $\mathrm{C}_{23} \mathrm{H}_{27}{ }^{79} \mathrm{Br}_{4}{ }^{-}$

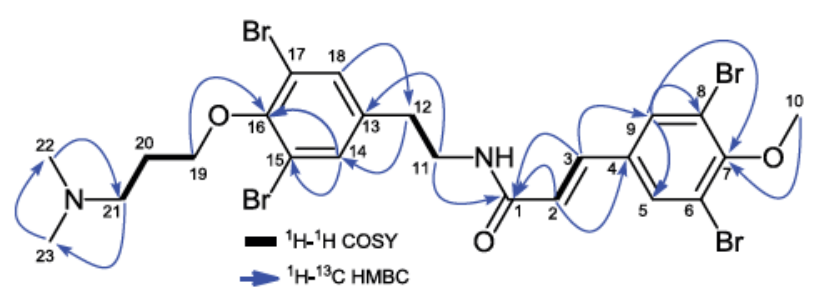

Fig. 3. Key ${ }^{1} \mathrm{H}-{ }^{1} \mathrm{H}$ COSY and ${ }^{1} \mathrm{H}-{ }^{13} \mathrm{C}$ HMBC correlations for 2.

$\mathrm{N}_{2} \mathrm{O}_{3}^{+}, 694.8750$ ) requiring ten degrees of unsaturation. The ${ }^{1} \mathrm{H}$ and ${ }^{13} \mathrm{C}$ NMR data of 2 displayed the resonances of a trans- $\alpha, \beta$-unsaturated carbonyl group, two symmetrical 1,2,4,6-tetrasubstituted aromatic rings, five methylenes, one of which was oxygenated, two $\mathrm{N}$-methyl groups and one $\mathrm{O}$-methyl group (Table 1 ). 


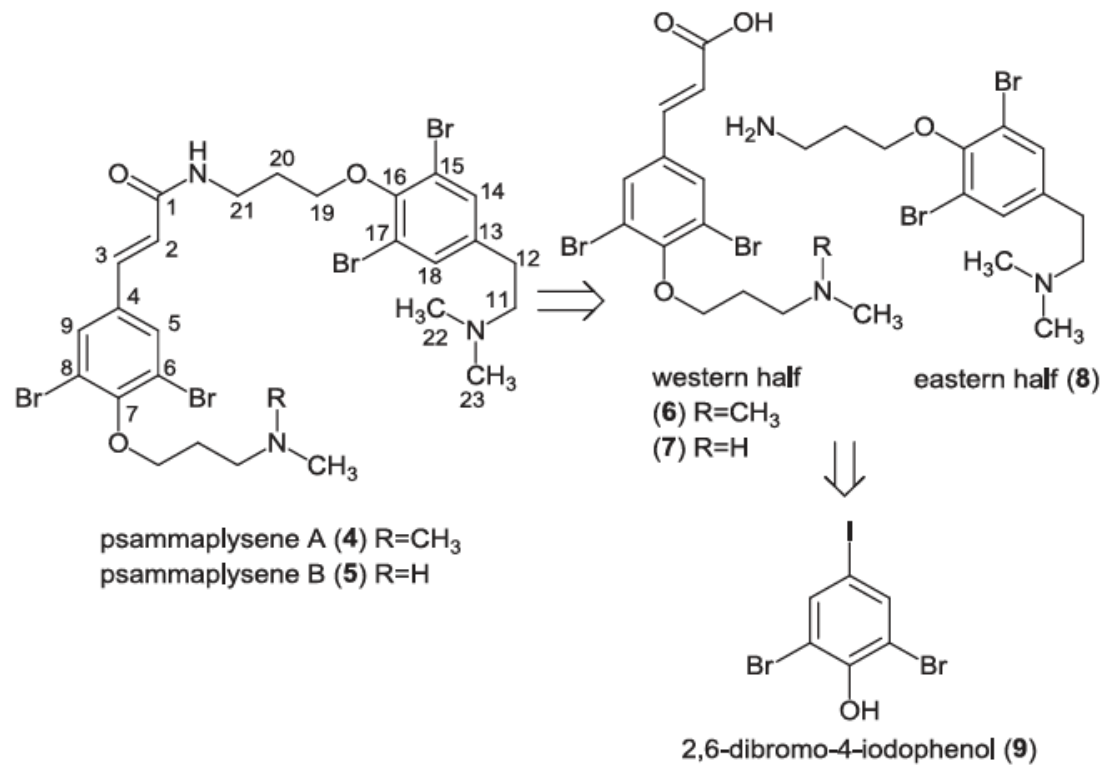

Fig. 4. Main retrosynthetic disconnection for psammaplysenes A (4) and B (5).

Interpretation of the ${ }^{1} \mathrm{H}-{ }^{1} \mathrm{H}$ COSY correlations between $\mathrm{H}-2$ and $\mathrm{H}-$ 3 reveal the connectivity of $\mathrm{C}-2$ to $\mathrm{C}-3$, between $\mathrm{H}-11$ and $\mathrm{H}-12$, reveal the connectivity of $\mathrm{C}-11$ to $\mathrm{C}-12$ and between $\mathrm{H}-19, \mathrm{H}-20$ and $\mathrm{H}-21$, the propyl spin system C-19-C-20-C-21 (Fig. 3). The different partial structures were then linked together by interpretation of the correlations observed in the ${ }^{1} \mathrm{H}-{ }^{13} \mathrm{C}$ HMBC spectrum. The $\mathrm{N}$-methyl $\mathrm{H}-22$ and $\mathrm{H}-23\left(\delta_{\mathrm{H}} 2.63\right)$ showed correlations to $\mathrm{C}$ $22, \mathrm{C} 23\left(\delta_{\mathrm{C}} 44.3\right)$ and $\mathrm{C}-21\left(\delta_{\mathrm{C}} 57.1\right)$. The correlation from $\mathrm{H}-19$ $\left(\delta_{\mathrm{H}} 2.63\right)$ to $\mathrm{C}-16\left(\delta_{\mathrm{C}} 152.3\right)$ linked the $O$-methylene to the first $1,2,4,6$-tetrasubstitued aromatic ring. The substitution of the aromatic moiety was suggested by the correlations from $\mathrm{H}-14, \mathrm{H}-18$ $\left(\delta_{\mathrm{H}} 7.50\right)$ to $\mathrm{C}-12\left(\delta_{\mathrm{C}} 34.9\right), \mathrm{C}-15\left(\delta_{\mathrm{C}} 118.7\right), \mathrm{C}-16\left(\delta_{\mathrm{C}} 152.3\right)$ and C-17 $\left(\delta_{\mathrm{C}} 118.7\right)$, from $\mathrm{H}-12\left(\delta_{\mathrm{H}} 2.82\right)$ to $\mathrm{C}-14\left(\delta_{\mathrm{C}} 134.2\right)$ and from $\mathrm{H}-11\left(\delta_{\mathrm{H}} 3.51\right)$ to $\mathrm{C}-13\left(\delta_{\mathrm{C}} 139.9\right)$. The $\mathrm{N}$-methylene $\mathrm{C}-11$ was linked to the carbonyl moiety by the correlation from $\mathrm{H}-11$ to $\mathrm{C}-$ $1\left(\delta_{\mathrm{C}} 171.0\right)$. The trans- $\alpha, \beta$-unsaturation was demonstrated by the correlation from $\mathrm{H}-2\left(\delta_{\mathrm{H}} 6.52\right)$ to $\mathrm{C}-1$ and from $\mathrm{H}-3\left(\delta_{\mathrm{H}} 7.37\right)$ to $\mathrm{C}-1$. The substitution of the second 1,2,4,6-tetrasubstitued aromatic ring was explained by the correlations from $\mathrm{H}-2$ to $\mathrm{C}-4\left(\delta_{\mathrm{C}}\right.$ $135.1)$, from $\mathrm{H}-3$ to $\mathrm{C}-5, \mathrm{C}-9\left(\delta_{\mathrm{C}} 132.8\right)$, from H-5, H-9 $\left(\delta_{\mathrm{H}} 7.79\right)$ to C-5, C-6 ( $\left.\delta_{\mathrm{C}} 119.3\right), \mathrm{C}-7\left(\delta_{\mathrm{C}} 156.1\right), \mathrm{C}-8\left(\delta_{\mathrm{C}} 119.3\right), \mathrm{C}-9$ and from the $O$-methyl $\mathrm{H}-10\left(\delta_{\mathrm{H}} 3.88\right)$ to $\mathrm{C}-7$.

Psammaplysenes previously isolated from two sponges, Psammaplysilla sp. ${ }^{10}$ and Psammoclemma sp., ${ }^{11}$ are known to possess interesting biological activities. To avoid the limited supply of material from sponge collections, Georgiades and Clardy have developed an efficient synthesis of psammaplysenes A (4) and B (5) as well as other derivatives. ${ }^{12,13}$ They first considered a retrosynthetic disconnection at the amide bond (Fig. 4) yielding two fragments 6 (or 7) and 8. Both of these fragments could be synthetized from the 2,6-dibromo-4-iodophenol (9). Due to the great similarities between 2, 4 and 5 (see comparison of the ${ }^{1} \mathrm{H}$ and ${ }^{13} \mathrm{C}$ NMR data for psammaplysenes $\mathrm{A}$ and $\mathrm{E}$, Table 2) and in the light of this work, a similar retrosynthetic pathway with a disconnection at the amide bond could also be envisaged for psammaplysene E (2) (Fig. 5). Although similar to the fragments 6 and $\mathbf{8}$, the two synthons 10 and 11 for psammaplysene E (2) show some differences. Compound 10 differs from $\mathbf{6}$ by a methoxy group instead of a $\mathrm{N}, \mathrm{N}$-dimethylamine-3-propoxy group. Compound 11 differs from $\mathbf{8}$ by the substitutions of the amines, the primary amine of $\mathbf{8}$ is replaced by a tertiary amine for $\mathbf{1 1}$ and the tertiary amine of $\mathbf{8}$ is replaced by a primary amine for $\mathbf{1 1}$. Thus, as the primary amine
Table 2

Comparison of ${ }^{1} \mathrm{H}$ and ${ }^{13} \mathrm{C}$ NMR data for psammaplysene $\mathrm{A}(4)^{10}$ and psammaplysene $\mathrm{E}(2)\left(\mathrm{CD}_{3} \mathrm{OD}\right)$.

\begin{tabular}{|c|c|c|c|c|}
\hline \multirow[t]{2}{*}{ Position } & \multicolumn{2}{|l|}{$\delta_{\mathrm{C}}$} & \multicolumn{2}{|l|}{$\delta_{\mathrm{H}}(\mathrm{J}$ in $\mathrm{Hz})$} \\
\hline & 2 & 4 & 2 & 4 \\
\hline 1 & 167.6 & 167.5 & - & - \\
\hline 2 & 123.6 & 124.1 & $6.52(1 \mathrm{H}, \mathrm{d}, 15.7)$ & $6.64(1 \mathrm{H}, \mathrm{d}, 15.7)$ \\
\hline 3 & 138.1 & 137.6 & $7.37(1 \mathrm{H}, \mathrm{d}, 15.7)$ & $7.39(1 \mathrm{H}, \mathrm{d}, 15.7)$ \\
\hline 4 & 135.1 & 135.8 & - & - \\
\hline 5 & 132.8 & 132.8 & $7.79(1 \mathrm{H}, \mathrm{s})$ & $7.82(1 \mathrm{H}, \mathrm{s})$ \\
\hline 6 & 119.3 & 119.3 & - & - \\
\hline 7 & 156.1 & 154.2 & - & - \\
\hline 8 & 119.3 & 119.3 & - & - \\
\hline 9 & 132.8 & 132.8 & $7.79(1 \mathrm{H}, \mathrm{s})$ & $7.82(1 \mathrm{H}, \mathrm{s})$ \\
\hline 10 & 60.9 & - & $3.88(3 \mathrm{H}, \mathrm{s})$ & - \\
\hline 11 & 41.5 & 59.0 & $3.51(2 \mathrm{H}, \mathrm{t}, 7.1)$ & $3.27(2 \mathrm{H}, \mathrm{t}, 7.0)$ \\
\hline 12 & 34.9 & 30.3 & $2.82(2 \mathrm{H}, \mathrm{t}, 7.0)$ & $3.00(2 \mathrm{H}, \mathrm{t}, 7.0)$ \\
\hline 13 & 139.9 & 136.8 & - & - \\
\hline 14 & 134.2 & 134.1 & $7.50(1 \mathrm{H}, \mathrm{s})$ & $7.59(1 \mathrm{H}, \mathrm{s})$ \\
\hline 15 & 118.7 & 119.1 & - & - \\
\hline 16 & 152.3 & 153.2 & - & - \\
\hline 17 & 118.7 & 119.1 & - & - \\
\hline 18 & 134.2 & 134.1 & $7.50(1 \mathrm{H}, \mathrm{s})$ & $7.59(1 \mathrm{H}, \mathrm{s})$ \\
\hline 19 & 71.6 & 71.7 & $4.07(2 \mathrm{H}, \mathrm{t}, 5.8)$ & $4.07(2 \mathrm{H}, \mathrm{t}, 7.0)$ \\
\hline 20 & 27.4 & 30.5 & $2.15(2 \mathrm{H}, \mathrm{m})$ & $2.13(2 \mathrm{H}, \mathrm{q}, 7.0)$ \\
\hline 21 & 57.1 & 36.6 & $3.07(2 \mathrm{H}, \mathrm{t}, 7.3)$ & $3.60(2 \mathrm{H}, \mathrm{t}, 7.0)$ \\
\hline 22 & 44.3 & 43.3 & $2.63(3 \mathrm{H}, \mathrm{s})$ & $2.87(3 \mathrm{H}, \mathrm{s})$ \\
\hline 23 & 44.3 & 43.3 & $2.63(3 \mathrm{H}, \mathrm{s})$ & $2.87(3 \mathrm{H}, \mathrm{s})$ \\
\hline
\end{tabular}

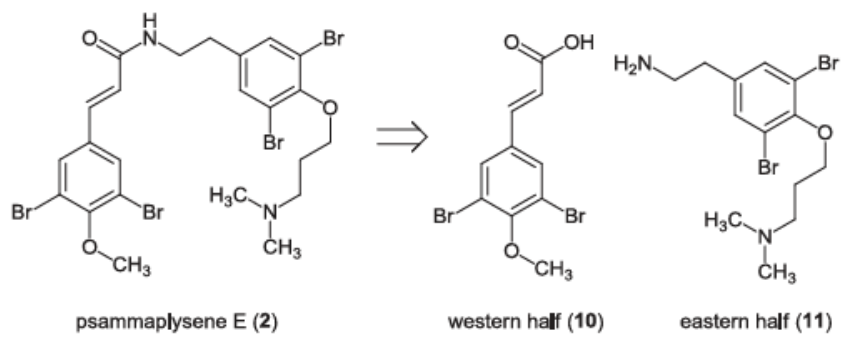

Fig. 5. Hypothetic main retrosynthetic disconnection for psammaplysene E (2).

is not located on the same side-chain, the skeleton obtained after the final coupling step between the primary amine of the "eastern half" and the carboxylic acid of the "western half", will be different 


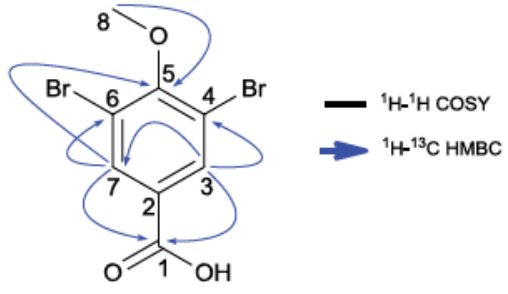

Fig. 6. Key ${ }^{1} \mathrm{H}_{-}{ }^{13} \mathrm{C}$ HMBC correlations for 3 .

between psammaplysene E (2) and psammaplysenes A (4) and B (5) (Fig. 6).

3,5-Dibromo-4-methoxybenzoic acid (3) was obtained as a colorless oil. Although known, no spectral data has been reported in the literature for this compound. Therefore, as it was not possible to compare our data with those previously published, the structure was completely elucidated. The HRESIMS showed a cluster of isotopic $[\mathrm{M}-\mathrm{H}]^{-}$peaks at $\mathrm{m} / \mathrm{z} 306.8618,308.8576$ and 310.8582 in a $1: 2: 1$ ratio, respectively. The molecular formula was deduced to be $\mathrm{C}_{8} \mathrm{H}_{6} \mathrm{Br}_{2} \mathrm{O}_{3}$ (calcd for $\mathrm{C}_{8} \mathrm{H}_{5}{ }^{79} \mathrm{Br}_{2} \mathrm{O}_{3}^{-}, 306.8611$ ) indicating five degrees of unsaturation. The ${ }^{1} \mathrm{H}$ and ${ }^{13} \mathrm{C}$ NMR data of 3 displayed the resonances of one carboxylic acid group, one symmetrical 1,2,4,6-tetrasubstituted aromatic ring and one $O$-methyl group (Table 1). There was no ${ }^{1} \mathrm{H}-{ }^{1} \mathrm{H}$ COSY correlation. The substitution of the 1,2,4,6-tetrasubstituted aromatic ring was established by ${ }^{1} \mathrm{H}-{ }^{13} \mathrm{C}$ HMBC correlations from $\mathrm{H}-3, \mathrm{H}-7 \quad\left(\delta_{\mathrm{H}} 8.12\right)$ to $\mathrm{C}-1$ $\left(\delta_{\mathrm{C}} 171.0\right), \mathrm{C}-3\left(\delta_{\mathrm{C}} 134.7\right), \mathrm{C}-4\left(\delta_{\mathrm{C}} 118.0\right), \mathrm{C}-5\left(\delta_{\mathrm{C}} 156.6\right), \mathrm{C}-6$ $\left(\delta_{\mathrm{C}} 118.0\right)$ and $\mathrm{C}-7\left(\delta_{\mathrm{C}} 1134.7\right)$ and from $\mathrm{H}-8\left(\delta_{\mathrm{H}} 3.87\right)$ to $\mathrm{C}-5$.

Amphimedonoic acid (1), psammaplysene E (2) are both bromotyrosine-derivated alkaloids. The genus Amphimedon has proved to be a powerful producer of various alkaloids with diverse structures, such as manzanine analogs or 3-alkylpyridine alkaloids, ${ }^{3,4,14,15}$ but this is the first report of bromotyrosinederivated metabolites from Amphimedon sponges. Some of these metabolites have also been isolated from an Oceanapia sp. sponge and a Psammoclemma sp. sponge, ${ }^{11,16}$ except that they have been limited exclusively to sponges of the order Verongida and were considered as one of the most solid chemotaxonomic groupings among the Porifera until recent years. ${ }^{17}$

Amphimedonoic acid (1), psammaplysene E (2) and 3,5dibromo-4-methoxybenzoic acid (3) did not show in vitro cytotoxicity against human epidermoid carcinoma KB cells $\left(\mathrm{IC}_{50}>10 \mu \mathrm{g} / \mathrm{mL}\right)$.

\section{Acknowledgments}

The authors gratefully acknowledge financial support from the European Commission and the Regional Council of Reunion Island: BIOMOL-TCN program (Activités Thérapeutiques, Cosmétologiques et Nutraceutiques de Molécules Issues de la Biodiversité Terrestre, Marine et Microbienne de la Zone Sud-Ouest de l'Océan Indien), ERDF (European Regional Development Fund). We thank Jerôme Bignon for cytotoxicity bioassays. The authors also express their gratitude to Prof. M. E. Remanevy for assistance in sponge collection.

\section{A. Supplementary data}

Supplementary data associated (experimental section, compound characterization, UV spectrum, ${ }^{1} \mathrm{H}, \mathrm{HSQC}, \mathrm{HMBC}, \mathrm{COSY}$ and HRESIMS spectra of compounds 1, 2 and 3) with this article can be found, in the online version, at http://dx.doi.org/10.1016/j. tetlet.2017.08.072.

\section{References}

1. Blunt JW, Copp BR, Keyzers RA, Munro MHG, Prinsep MR. Nat Prod Rep. 2014;31:160-258.

2. Albrizio S, Ciminiello P, Fattorusso E, Magno S, Pawlik JR. J Nat Prod. 1995;58:647-652.

3. Takahashi Y, Kubota T, Fromont J, Kobayashi J. Org Lett. 2009;11:21-24.

4. Kubota T, Kamijyo Y, Takahashi-Nakaguchi A, Fromont J, Gonoi T, Kobayashi J. Org Lett. 2013;15:610-612.

5. Gauvin-Bialecki A, Aknin M, Smadja J. Molecules, 2008;13:3184-3191.

6. Gros E, Al-Mourabit A, Martin M-T, et al. J Nat Prod. 2014;77:818-823.

7. Campos P-E, Wolfender J-L, Queiroz E, et al. J Nat Prod. 2017;80:1404-1410.

8. Venkateswarlu Y, Chavakula R. J Nat Prod. 1995;58:1087-1088.

9. Tian L-W, Feng Y, Shimizu Y, et al. J Nat Prod. 2014;77:1210-1214.

10. Schroeder FC, Kau TR, Silver PA, Clardy J. J Nat Prod. 2005;68:574-576.

11. Buchanan MS, Carroll AR, Addepalli R, Avery VM, Hooper JNA, Quinn RJ. J Nat Prod. 2007;70:1827-1829.

12. Georgiades SN, Clardy J. Org Lett. 2005;7:4091-4094.

13. Georgiades SN, Clardy J. Org Lett. 2006;8:4251-4254.

14. Yamada M, Takahashi Y, Kubota T, et al. Tetrahedron. 2009;65:2313-2317.

15. Nishi T, Kubota T, Fromont J, Sasaki T, Kobayashi J. Tetrahedron. 2008;64:3127-3132.

16. Nicholas GM, Newton GL, Fahey RC, Bewley CA. Org Lett. 2001;3:1543-1545. 17. Tilvi S, Rodrigues C, Naik CG, Parameswaran PS, Wahidhulla S. Tetrahedron. 2004;60:10207-10215. 